\author{
Martynas Lukoševičius* \\ Ministry of Foreign Affairs of the Republic of Lithuania*
}

\title{
European Union Sanctions Policy
}

This article analyses the sanctions policy conducted by the European Union and names it one of the most frequently used instruments of its foreign policy. It also shortly encompasses the sanctions imposed to the third countries by the EU, putting a special emphasis on the restrictions to the states not subject to the United Nations sanctions. The article concludes that, despite the active usage of the sanctions instrument by the EU, they can be assessed as a political signal to a target country but without any concrete impact on its internal or external policies. A long list of sanctioned country over time corresponds to this conclusion. The article describes the Lithuanian policy in implementing the sanctions as well as states that there is no national legislation in Lithuania in order to impose unilateral sanctions.

\section{Introduction}

The Charter of the United Nations states that, "the parties to any dispute, the continuance of which is likely to endanger the maintenance of international peace and security, shall, first of all, seek a solution by negotiation, enquiry, mediation, conciliation, arbitration, judicial settlement, resort to regional agencies or arrangements, or other peaceful means of their own choice"1.

In case of a conflict, the United Nations Security Council decides what non-military measures are to be employed to restore international peace and security ${ }^{2}$. This provision of Article VII of the Charter legitimizes international sanctions as an instrument of international politics.

Sanctions can be treated on an international level when they are imposed by international or regional organizations, so it is obvious that the Member States of the European Union (EU) imposed sanctions on the EU level, or implement them after the imposition of other international organizations in order to coordinate their foreign policy. However, Lithuania implements the international sanctions imposed by the United Nations (UN), European Union

\footnotetext{
"Martynas Lukoševičius is a diplomat, since September 2009 he serves as a Third Secretary and the Embassy of the Republic of Lithuania to the Federal Republic of Germany. In 2005-2009 he worked at the Division of Arms Control and Terrorism Prevention of the Transatlantic Cooperation and Security Policy Department of the Ministry of Foreign Affairs of the Republic of Lithuania, tel. +37068247411, e-mail: martynasl@ hotmail.com.

** The views and evaluations expressed in this article are purely those of the writer and may not in any circumstances be regarded as stating an official position of the Ministry of Foreign Affairs of the Republic of Lithuania and its institutions.

${ }^{1}$ Article 33 of Chapter VI of the Charter of the United Nations.

${ }^{2}$ Ibidem, Article 33 of Chapter VI.
} 
(EU) and Organization for Security and Co-operation in Europe (OSCE) but has no unilateral sanctions to any subject. This corresponds to the assessment that sanctions on an international level give more impact and cause less damage to the imposing state than in comparison to unilateral sanctions ${ }^{3}$.

This article aims to describe the international sanctions imposed by the European Union and their issues - the way they echo the sanctions imposed by the United Nations Security Council (further referred as UNSC), the cases of unilateral imposition, and their general efficiency as and instrument of international politics in order to achieve certain goals.

The article also seeks to demonstrate that the EU, in comparison to other foreign policy measures, uses the instrument of international sanctions in a effective and abundant way in order to achieve its foreign policy goals despite the fact that the internal negotiations upon their impositions requires much time. Neglecting this detail, the EU sanctions policy can be regarded as one of the most legally and technically determined areas of foreign policy making.

We must admit that references about the sanctions issues, especially in Lithuanian, is rather incomplete and it hardly gives any information about the impact of sanctions on a targeted country. One of the more distinguishable Lithuanian authors is jurist Dovydas Špokauskas who chose for his analysis an important topic, i.e. issues of human rights in implementation of international sanctions ${ }^{4}$. In the absence of a systematic analysis describing current international sanctions implemented by the EU, this article should become a stepping-stone for further research in the sphere of international sanctions, it should also have as well a practical use for those interested in, or working with, the implementation of international sanctions.

Before starting to write about the subject of international sanctions, it is advisable to pay attention to the term "sanctions" which in some legislation is replaced by the phrase "restrictive measures" (lith. "ribojančios priemonès", fr. "mesures restrictives", germ. "restriktive Maßnahmen"). On the website of the EU Commission ${ }^{5}$ both terms are treated as synonyms and neither of them has an additional value. Joakim Kreutz provides us with an interpretation as to why these two terms still survive, especially the indirectly comprehensible term "restrictive measures", giving an idea that the EU treats itself as a "soft power", therefore its institutions are avoiding the use of stricter terms despite the fact that according to the definition provided by the United Nations, and to the usage by various states, both terms have the same meaning ${ }^{6}$.

\footnotetext{
${ }^{3}$ Akehurst M., Malanczuk P., Šiuolaikinis tarptautinès teisès ivvadas [Modern Introduction To International Law], Vilnius, Eugrimas, 2000, p. 29 (in Lithuanian).

${ }^{4}$ Špokauskas D. "Žmogaus teisių apsauga taikant tarptautines sankcijas" ["The Preservation of Human Rights in Implementation of International Sanctions", Teise [The Law] 64, 2007 (in Lithuanian).

5 "Sanctions or restrictive measures in force".

(iš http://ec.europa.eu/external_relations/cfsp/sanctions/index_en.htm, 1512 2009).

${ }^{6}$ Kreutz J., Hard Measures by a Soft Power? Sanctions Policy of the European Union, Bonn International Center for Conversion, 2005, http://www.bicc.de/uploads/pdf/publications/papers/paper45/paper45.pdf, 15122009 .
} 
For the sake of brevity and clarity in this article, the priority is given to the term "sanctions", moreover its synonym "restrictive measures" in Lithuanian seems to be a literal translation from foreign languages.

\section{International Sanctions: Types, Objects and Scope}

The Law of the Implementation of Economic and Other International Sanctions of the Republic of Lithuania ${ }^{7}$ provides us with an explicit list of the main types of international sanctions: economic, financial, political, communication, and public. It is a logical and definite grouping of international sanctions applicable not only for the Lithuanian practice. The universality of this Lithuanian law could be explained by the fact that Lithuania, before it joined the EU, had no "specific legislation controlling social sphere in case of the state should apply sanctions to other states, informal organizations, legal and natural persons" ${ }^{\prime \prime}$. Lithuania's membership in the EU was led by the requirement to prepare and adopt a national legal act on international sanctions and it created good conditions to accumulate "good practice" of the already EU member states, which were asked to share it as well as to directly take over the EU provisions. This is the reason why Lithuanian legislation suggests a coherent classification of international sanctions and a description of their implementation. One must remark that this law was adopted on 22 April 2004, i.e. just a week ahead of Lithuanian membership in the EU.

It is worth remarking that usually economic (arms embargo), financial (freeze of assets), and political (visa ban) sanctions are the most preferred as they could be easier defined and their implementation to be controlled as of relatively vague communication and public sanctions.

Economic sanctions refers to restrictions on the import, export, re-export, and transit, including brokering, of goods for civil purposes, dual-use items, military equipment, services, and technologies (in other words - arms embargo); restrictions on the trade with entities with respect to which international sanctions are implemented; restrictions on economic activities of natural and legal persons of the Republic of Lithuania in a state or territory with respect to which international sanctions are implemented; restrictions on economic activities in the territory of the Republic of Lithuania of the entities with respect to which international sanctions are implemented. Radical economic sanctions could be described as a boycott and blockade: the first referring to suspension of any economic relations and the latter meaning the physical isolation of the country that no foreign trade could be conducted ${ }^{9}$.

\footnotetext{
${ }^{7} 22$ Aril 2004, No IX-2160.

${ }^{8}$ Article 3 of Resolution of the Government of the Republic of Lithuania No 1661 "On the Approval of the Conception of the Law on Economic and Other International Sanctions of the Republic of Lithuania" (27 December 2003, Official Gazette 2005, No 122-5528).

${ }^{9} \mathrm{~V}$. Vadapalas provides with an example of Iraq which, after the invasion to Kuwait in 1990, was a subject of economic boycott and blockade according to UNSC resolutions No 661 (1990) and 665 (1990). According to Vadapalas V., Tarptautine teisé: bendroji dalis [International Law: Common Part], Vilnius: Eugrimas, 1998, p. 348 (in Lithuanian).
} 
Financial sanctions refers to restrictions on the rights of entities, with respect to which international sanctions are implemented, to manage, use and dispose of cash, securities, goods, other assets and property rights; payment restrictions for entities with respect to which international sanctions are implemented; other restrictions on financial activities. It is worth noticing that financial sanctions do not lead to the deprivation of the assets of persons subject to sanctions but forbid for a certain period to use them and profit.

Political sanctions refers to restrictions on official visits; restrictions on entry into, or transit through, a state or a territory with respect to which international sanctions are implemented; restrictions on entry into, or transit through, the territory of the Republic of Lithuania for the persons with respect to whom international sanctions are implemented; restrictions on diplomatic relations; other measures of political and diplomatic influence.

Rarely used communication sanctions are described as restrictions on transport (rail, road, water, air), postal, electronic, and (or) other communication with entities with respect to which international sanctions are implemented.

Lastly, public sanctions refer to restrictions on cultural, scientific, educational, sports, and other public relations with entities with respect to which international sanctions are implemented.

The objects of international sanctions can be states, natural and legal persons and other subjects whose actions, decision or current policy violate human rights, contribute to ethnic, territorial and religious conflicts, promote terrorism or by any other way breach the core norms and principles supported by international community. The objects can include representatives of national governments, companies producing strategic goods (arms), logistic companies, certain banks or sensitive industry branches in various countries (e.g. diamonds in Liberia and timber in Myanmar). International sanctions could be also determined and regarded as measures of non-military impact that aim to change the current policy of certain countries, its government or of its part, other subjects and persons and stop concrete activities breaching the norms of international law.

The implementation of international sanctions is based not on the economic interests but on the principles of international law, democracy, respect for human rights and principal freedoms. For instance, the EU when implementing the sanctions imposed by other international organizations or imposing on its own refers to Article 6 of the Treaty on European Union declaring that "the Union shall respect fundamental rights, as guaranteed by the European Convention for the Protection of Human Rights and Fundamental Freedoms signed in Rome on 4 November 1950 and as they result from the constitutional traditions common to the Member States, as general principles of Community law"10.

The same level of importance is accredited to the principles of proportionality and expediency, which are regarded when sanctions are targeted to

${ }^{10}$ Article 6 of the Treaty on European Union. 
subjects responsible for current policy and concrete activity but not to the entire population of a sanctioned country ${ }^{11}$.

On imposition of sanctions, the scope is defined in details: in case of arms embargo concrete lists of goods or technologies forbidden to export shall be drawn up, as well as a period for termination of sanction or their revision shall be foreseen. Separately, certain exceptions on the applicability of sanctions are emphasized and their concrete circumstances, as well as institution in charge of their implementation are set out. Exceptions usually cover the use of frozen assets for humanitarian aims (provision of food and medicine), cost of legal proceedings; in case of arms embargo military equipment are allowed to be exported to UN missions or to provide diplomatic representations or journalists with protection equipment.

\section{The Implementation of International Sanctions in the European Union}

The European Union being an international organization joined by 27 states adopts legislation on the implementation of international sanctions binding its member states. The major part of these sanctions were adopted by the United Nations Security Council and the EU simply transposes them to the legal system of the Community - certain types of the legislation of the Community define their scope and the level of obligation to implement. In some cases the EU has specific foreign policy aims and adopts additional, so-called autonomic sanctions, which are applied only by member states. This chapter describes common issues revolving around the adoption and implementation of EU sanctions and these two types thereof: the sanctions transposed by the EU and its autonomic ones.

\subsection{Basic Principles of the Sanctions Applied by the EU}

The EU sanctions policy is regarded as one of the instruments of the Common Foreign and Security Policy (CFSP), which can be used by the Community in implementation of its objectives enlisted in Article 11 of the Treaty on European Union ${ }^{12}$ :

\footnotetext{
${ }^{11}$ Sometimes these specifically targeted sanctions are entitled as "smart sanctions". According to Evans M., ed., International Law, 2nd Editon, Oxford University Press, 2006, p. 529.

${ }^{12}$ Article 11 of the Treaty on European Union. The adoption and implementation of sanctions are set out in details in the following specific EU documents: 1) Basic Principles on the Use of Restrictive Measures, 2) Guidelines on Implementation and Evaluation of Restrictive Measures in the Framework of the EU Common Foreign and Security Policy, 3) EU Best Practices for the Effective Implementation of Restrictive Measures (these document are available on the Website of the EU Commission http://ec.europa.eu/external_relations/ cfsp/sanctions/index_en.htm, 1512 2009).
} 
- To safeguard the common values, fundamental interests and independence of the Union;

- To strengthen the security of the Union and its Member States in all ways;

- To preserve peace and strengthen international security in accordance with the principles of the United Nations Charter, as well as the principles of the Helsinki Final Act, and the objectives of the Paris Charter;

- To promote international cooperation; and

- To develop and consolidate democracy and the rule of law, and also respect for human rights and fundamental freedoms.

The sanctions in force must be applied to targeted objects in sanctioned countries without breaching the interest of citizens and companies of these countries; the applied measures must not have impeded the agreements of the World Trade Organization (WTO) as well. To these ends, the lists of sanctioned persons shall be compiled, including their accurate identification details, conditions and procedures of their enlisting and de-listing. Freezing of assets shall have its validity period, as well as arms embargoes shall be applicable only for the equipment included in control lists. These principles of the EU should lead to greater political transparency and legal clarity with special attention to the respect of human rights. Lately some people coming from third countries have started legal proceedings ${ }^{13}$ in order to prove that they have been arbitrarily included into the list of sanctioned persons. To avoid such cases, there is a trend at the stage of sanctions adoption to submit all available proofs on criminal acts of such individuals and even to set out these proofs in the EU legislation ${ }^{14}$.

It is also important to emphasize that the Union does not adopt any legislation with exterritorial applicability, i.e. biding the citizens and subject of third countries, on its assumption that it impedes the international law. On these grounds it also denounces such legislation of other countries and foresees appropriate sanctions on third countries if their legislation has an exterritorial applicability over these natural and legal persons of the EU member states ${ }^{15}$.

Implementing international sanctions adopted by the United Nations

\footnotetext{
${ }^{13}$ E.g. Case T-256/07 of the Court of First Instance of the European Union where the entity "People's Mojahedin Organization of Iran" attempted to prove that it was unjustified subjected to sanctions. Other example denotes Case T-85/09 of Yassin Abdullah Kadi versus the EU Commission. This person claimed about arbitrary inclusion to the sanctions list: neither appropriate UN decision nor circumstances to defend himself and submit vindication were provided, as well as the Commission has not presented reasons for freezing of his assets. He has also claimed that Regulation (EC) No 1190/2008 imposing sanctions upon him was appropriately applied to restrain his ownership proportionally.

${ }^{14}$ E.g. Council Common Position 2008/652/CFSP amending Common Position 2007/140/CFSP concerning restrictive measures against Iran provides with list of sanctioned individuals where the reasons of their enlisting are also available.

${ }^{15}$ E.g. Council Regulation (EC) No 2271/96 of 22 November 1996 protecting against the effects of the extra-territorial application of legislation adopted by a third country, and actions based thereon or resulting therefrom.
} 
Security Council and according to Article 15 of the Treaty on European Union ${ }^{16}$, the EU Council adopts common positions setting out political obligations for member states to implement certain sanctions. In this case, member states shall adopt national legislation implementing common positions. In areas where the Union possesses its exclusive competence, additional regulations having direct applicability are also adopted. The exclusive competence of the Union embraces trade restrictions, prohibition to provide with assistance, and freezing of assets. On the other hand, embargo on military equipment and visa ban remains within the competence of member states as a part of CFSP.

Common positions set out all sanctions imposed to certain subjects, even if some of them are included into regulations. In order to avoid any transitional period when member states have to implement sanctions according to common positions, including those of the exclusive competence of the Union, appropriate regulations are usually adopted at the same time as in practice their contents do not drastically diverge from each other and both documents are prepared in common.

In order to append the sanctions imposed by common positions and regulations, the Council is empowered to adopt limited scope decisions, for instance, on inclusion of new individuals into visa ban lists, as well as the Commission can adopt regulations on inclusion of individuals into lists of asset freezing.

Specific measures to implement sanctions shall be adopted on a national level but in cases where no directly applicable regulations are adopted (i.e. in cases of common positions only), some states decide to implement common positions directly on the national level. Moreover, competent national authorities are always entitled to impose penalties in case of infringement of sanctions regime, grant exceptions, as well as exchange of information and submit national reports on implementation.

In some cases it is not true that regulations of direct applicability and imposing sanctions are not subject of implementation by member states adopting national by-laws. Regulations set out certain sanctions to subjects only but they do not provide states with the method of implementation. The differences among national legal systems and the practice of the EU member states stills exist, no common or "European" rules could be laid down, so an accurate mechanism for implementation shall be adopted on the national level ${ }^{17}$.

Nevertheless, the EU Council has adopted the Guidelines on Implementation and Evaluation of Restrictive Measures in the Framework of the EU Common Foreign and Security Policy and "Best Practices" for the Effective

\footnotetext{
16 "The Council shall adopt decisions which shall define the approach of the Union to a particular matter of a geographical or thematic nature. Member States shall ensure that their national policies conform to the Union positions."

${ }^{17}$ The implementation of international sanction in Lithuania is set out in two main legal acts: The Law of the Implementation of Economic and Other International Sanction of 22 April 2004 (IX-2160) and Resolution of the Government No 1679 of 30 December 2004 "On the Approval of Order of Supervision on the Implementation of International Sanctions".
} 
Implementation of Restrictive Measures ${ }^{18}$ in order to unify various ways regarding the implementation of sanctions. These documents aim for the standardization and development of implementation methods, as well as the main issues, standard definitions and common wordings used in the EU legislation are presented. These papers are to be supposed as a step forward in order to minimize institutional discussions that usually appear during the process of adopting EU legislation.

The Working Party of Foreign Relation Counsellors (RELEX) is charged with preparing legislation when the EU implements international sanctions or autonomously imposes on its own. Depending on the case, a working party responsible for the relations with certain third countries can also be included in this process. The right to initiate appropriate sanctions belongs to the country holding the EU Presidency or to Commission acting upon Article 75 or 215 of the Treaty on European Union ${ }^{19}$ regarding restrictions on relations with third countries. The draft document is submitted for the debates at the Committee of Permanent Representatives (COREPER) and for the adoption at the Council.

It is worth noting that the discussions at the EU institutions on sanctions usually require a longer time: firstly, the reports from the Heads of Missions of the EU embassies in the countries under sanctions take some time, secondly, the interests of the EU subjects in sanctioned countries should be accommodated, as well as the procedures of adoption and legal implications halt the whole process. All these aspects cause the reality to be that the duration of adopting sanctions stretches up to several months.

\subsection{Issues of Implementation of the Sanctions Imposed by the UNSC}

At the moment (Autumn 2009), the EU implements the sanctions adopted by the United Nations Security Council against the following states (ref. Table 1 Currently Applied International Sanctions): Republic of Côte d'Ivoire, Iraq, Iran, Democratic Republic of the Congo, Democratic People's Republic

\footnotetext{
${ }^{18}$ The main documents describing the EU practice of the implementation of international sanctions are the following: 1) Basic Principles on the Use of Restrictive Measures, 2) Guidelines on Implementation and Evaluation of Restrictive Measures in the Framework of the EU Common Foreign and Security Policy, 3) EU Best Practices for the Effective Implementation of Restrictive Measures (these document are available on the Website of the EU Commission http://ec.europa.eu/external_relations/cfsp/sanctions/index_en.htm, 1512 2009).

19 "Where a decision, adopted in accordance with Chapter 2 of Title V of the Treaty on European Union, provides for the interruption or reduction, in part or completely, of economic and financial relations with one or more third countries, the Council, acting by a qualified majority on a joint proposal from the High Representative of the Union for Foreign Affairs and Security Policy and the Commission, shall adopt the necessary measures. It shall inform the European Parliament thereof" (Article 215). "Where necessary to achieve the objectives set out in Article 67, as regards preventing and combating terrorism and related activities, the European Parliament and the Council, acting by means of regulations in accordance with the ordinary legislative procedure, shall define a framework for administrative measures with regard to capital movements and payments, such as the freezing of funds, financial assets or economic gains belonging to, or owned or held by, natural or legal persons, groups or non-State entities" (Article 75).
} 
of Korea (North Korea), Lebanon, Liberia, Sierra Leone, Somalia and Sudan, as well as against the individuals and terrorist groups in relations with Osama bin Laden, Al Qaida and Taliban. The EU cannot restrict the scope of the sanctions imposed by the United Nations, so it acts as an implementing entity and the appropriate process can be described as a mechanical transposition of the UNSC resolutions into the legal system of the Union.

The main issue concerning transposition of the UN sanctions is the rapidity of adopting relevant legislation, especially in cases of freezing the funds of individuals in question, as they can be transferred to anybody at any time. For the sake of efficiency, this legislation should be adopted not later than 30 days after the adoption of relevant UNSC resolution. If these sanctions are already in force and only the corrections in the lists are needed, the Commission is entitled to act automatically in three days and adopt its regulation.

Difficulties arise when the EU member states must to implement binding UN documents but on the other hand they are in a position to wait for the adoption the EU legislation implementing those documents. It would be obviously inefficient to pass a piece of national legislation according to UNSC resolutions when in a month comes, for instance, a directly applicable EU Council regulation.

This problem is known to Lithuania as well, as the Law on the Implementation of Economic and Other International Sanctions of 2004 has an obligation that the sanctions adopted by the international organizations shall be implemented by resolutions of the Government in case of no EU regulations. In everyday life, to pass a resolution of the Government takes two months and this lead to a situation of no legislation in Lithuanian legal system until the adoption on EU sanctions. Article 60 of the Treaty on European Union after the amendments done in Amsterdam in 1997 foresaw possible provisional national measures, specifically in case of freezing of assets, but it was not put in practice ${ }^{20}$.

Another issue is the duration of sanctions. The UNSC usually revises the sanctions in force before the date or their termination, or do not set out a certain period of validation at all and provides only with circumstances or desired changes in a sanctioned state that could lead to the revocation of sanctions. The EU documents usually contain the period of validation, so the difficulties arise in order to harmonize the validity of the sanctions in UN and EU systems. In such cases it is very important for the EU to immediately cancel the international sanctions revoked by the UN - for this reason some EU legislation could even have a retrospective application.

In order to augment the cooperation of UN and EU institutions, and to solve the abovementioned issues, UN-EU joint seminars are organized every

20 "Without prejudice to Article 297 and as long as the Council has not taken measures pursuant to paragraph 1, a Member State may, for serious political reasons and on grounds of urgency, take unilateral measures against a third country with regard to capital movements and payments. The Commission and the other Member States shall be informed of such measures by the date of their entry into force at the latest." 
year in order to discuss technical question of implementation and coordination. The officials who are directly dealing with the implementation of sanctions and adoption of relevant legislation, for instance, representatives of the Working Party of Foreign Relation Counsellors (RELEX) are the most welcomed to these events.

In conclusion on the EU practice to implement the sanctions imposed by the UN, this practice could be considered as an obvious relief for the EU member states which has no further obligation to adopt national legislation where EU regulations already exist. In Lithuanian practice, political sanctions usually imposed by other documents than regulations are directly transposed into the Lithuanian legal system as well because relevant resolution of the Government provides with common rules and obligations for the authorities in charge of their implementation ${ }^{21}$. In spite of this general simplification, member states have to adopt appropriate by-laws setting out a detailed order for the implementation of international sanctions.

\subsection{EU Unilateral Sanctions as a Foreign Policy Instrument}

Unilateral or autonomous sanctions are considered as an instrument of the EU Common Foreign and Security Policy, which is used in order to affect certain states' foreign policy which in some cases violates human rights or to impose restrictions on individuals subject to war crimes. These sanctions cannot be regarded as technical implementation of international sanctions imposed by the United Nations.

At this moment (Autumn 2009) the autonomous sanctions imposed by the European Union can be divided into the following groups:

- Sanctions imposed for the infringements of human rights and internal repressions: against Belarus, Myanmar/Burma, China, Moldova (Transnistrian Region), Uzbekistan and Zimbabwe;

- Additional restriction to the UN sanctions against Iran;

- Sanctions against individuals indicated by International Criminal Tribunal for the former Yugoslavia: against certain citizens of Bosnia and Herzegovina, Croatia, Former Yugoslav Republic of Macedonia ${ }^{22}$ and Serbia;

- Sanctions against those who committed crimes: Syrian citizens suspected of involvement in the murder of former Prime Minister of the Lebanon, Rafiq Hariri;

- Specific sanctions against Haiti, Iraq, Libya and Serbia prohibiting to satisfy certain claims of these country for former sanctions regimes towards them;

- Sanctions against the USA prohibiting to apply certain US legislation having an exterritorial application (on the territory of third countries).

\footnotetext{
${ }^{21}$ Resolution of the Government No 639 of 6 June 2007 "On the Implementation of Political Sanctions Prohibit the Entry and Transit of Individuals through the Territory of the Republic of Lithuania".

${ }^{22}$ In case of Former Yugoslav Republic of Macedonia, visa ban was applied to persons challenging the Ohrid Framework Agreement.
} 
Autonomous sanctions are defined according the EU strategy and foreign policy towards certain countries and they are used to stimulate changes in them. It is extremely important to evaluate if the sanctions in force are proportional in order to achieve their goal, as well as to set out the indicators when they are to be lifted up. Upon imposition of sanctions, reasons of such decision and infringed international law norms are also written in a detailed manner. The EU stressing the importance of human rights and, in the same sway, protecting itself from possible lawsuit, for instance, for an illegal inclusion of persons into sanctions lists, is starting to frequently provide with the reasons of inclusion, even in cases of the UN sanctions already in force ${ }^{23}$.

\subsubsection{When UN Sanctions Are Not Sufficient}

One of the best examples of EU autonomous sanctions is the restrictions imposed against Iran and complementing sanctions imposed by the UN: i.e. additional political (movement) and financial sanctions against certain individuals; freezing of assets belonging to companies involved in nuclear and missile programs (among them there are a couple of bank having branches in foreign countries); prohibition to export related equipment and technologies, as well as vigilance towards certain companies and goods imported by them, which are not considered as of strategic importance but can be used in the abovementioned programs. The policy of autonomous sanctions towards Iran can be assessed as an instrument in a more global EU-Iran relationship seeking to prevent Iran from the acquisition of nuclear weapons. The EU has imposed a broader embargo than the UN on military equipment towards North Korea as well ${ }^{24}$.

The researches of International Atomic Energy Agency (IAEA) started in 2002, demonstrated that Iran had maintained secret uranium enrichment programs which make the acquisition of radioactive materials and other equipment possible. Following these conclusions, the USA and Israel accused Iran of concealment of nuclear program but at the same time China and Russia having with Iran trade in technologies demanded more obvious proofs about development of inappropriate programs.

In this context, the European Union saw an opportunity to contribute to the solution of the so-called "Iranian issue" - three EU member states (the United Kingdom, France and Germany - also referred as EU3) started negotiations with Iran in 2003. The talks ended in 2004 with the Paris Agreement where Iran promised to halt the uranium enrichment and reprocessing, as well as to start cooperation with the IAEA.

\footnotetext{
${ }^{23}$ Abovementioned Council Common Position 2008/652/CFSP amending Common Position 2007/140/CFSP concerning restrictive measures against Iran appeals to the UN sanction as a basis for enlisting.

${ }^{24}$ Council Common Position 2006/795/CFSP of 20 November 2006 concerning restrictive measures against the Democratic People's Republic of Korea imposed arms embargo. However, relevant UNSC resolution 1718 (2006) limits only the export of lethal military equipment (such as tanks, fighters, vessels etc.).
} 
Despite this agreement, in 2006, Iran stopped verifications carried out by the UN inspectors in its nuclear objects and declared about the renewal of uranium enrichment. Taking note to such actions, in 2006 and 2007, the United Nations Security Council adopted resolutions imposing sanctions against Iran. The EU immediately implemented these UN sanction, moreover, it adopted its own additional restrictions.

The same year the EU3, as well as Secretary-General of the EU Council and High Representative for CFSP, Javier Solana, suggested Iran a negotiation package providing with an active support to build a light water reactor instead of termination of Iranian nuclear program but Iran rejected these suggestions. After refusal, the EU started the process of an imposition of broader autonomous sanctions. In the end of 2007 the EU3 and other negotiating countries, the USA, Russian Federation and China, agreed upon a "two-way approach" denoting the development of a dialogue with Iran but also not to renounce their pressure through the implementation of international sanctions.

This example unveils the ways how the EU can use the imposition of sanctions for its foreign policy goals and strengthen its position among other actors of international politics. One question remains unanswered whether such sanctions policy is effective if Iran has not agreed to stop the development of its nuclear and missile programs.

It is also useful to remark that only additional sanctions imposed towards Iran are often considered as autonomous in order to emphasize that the EU supplements UN restrictions. Other sanctions imposed by the EU are directed to the countries that are not subject of international sanctions applied by the $\mathrm{UN}$ or these are insignificant.

\subsubsection{Additional Regards of the EU to the Defence of Human Rights}

The sanctions against Belarus was adopted in 2006 and are applied to individuals responsible for violations of international electoral standard in the presidential elections in Belarus on 19 March 2006, and the crackdown of civil society and democratic opposition, as well as against natural and legal persons, other subjects and institutions related to these individuals ${ }^{25}$ - there is a visa or transit ban in the territory of the EU and their assets are frozen. Nevertheless, in the beginning of 2009 the EU Council, seeking to promote its Neighbourhood Policy and encourage the Government of Belarus for democratic changes and respect of human rights and fundamental freedoms, decided to temporary suspend the application of political (movement) sanctions but it has not repealed them. There is a period of nine months foreseen at which the Council should monitor developments in these areas and decide upon further application or revocations of sanctions. This example demonstrates that the

\footnotetext{
${ }^{25}$ Common Position 2006/276/CFSP of 10 April 2006 concerning restrictive measures against certain officials of Belarus.
} 
EU uses the instrument of sanctions in order to motivate third countries to respect human rights; there are also exceptions if the situation in the countries seems to improve.

A similar policy is conducted in case of Uzbekistan. When Uzbek security forces used a disproportional force during events in Andijan in 2005 the EU imposed autonomous political, financial and some specific economic sanctions (not only arms embargo but restrictions to sell equipment intended for internal repressions al well). Uzbekistan was encouraged to completely meet its international obligations in the sphere of human rights and fundamental freedoms and allow a free monitoring on this process to be carried out by representatives of relevant international organizations. The Council in its conclusions in 2007 and 2008 emphasized a development in the area of human rights and temporary stopped the application of political sanctions but arms embargo remained in force. Every year the EU Council had to assess the situation in Uzbekistan and decide upon imposition or revocation of further restrictions - this was a reminder for the country that its internal situation is permanently observed.

It is worth noticing that the EU could not allow itself to react so independently to situations in third countries if the UN sanctions could be in force. Moreover, the EU when imposing autonomous sanctions is able to anchor its role as a subject of international politics and within the Union to better coordinate certain foreign policy spheres of its member states.

The restrictions against certain officials of the Transnistrian region can also be classified to the same domain. According to the EU position, Transnistria is an integral part of Moldova, so the sanctions are commonly referred as those against Moldova. Their object is persons responsible for the broad intimidation and closure campaign against teachers, parents and students of Latin-script Moldovan schools in the Transnistrian region. At the moment the situation is not improving, thus the EU retains its policy to apply political (movement) sanctions.

In order to find persons subject to war crimes and officially indicated by the International Criminal Tribunal for the former Yugoslavia, the EU imposed political and financial (freezing of assets) sanctions against certain citizens of Bosnia and Herzegovina, Croatia and Serbia. The number of these persons is limited and they are increasingly arrested. Similar sanctions are applied to the Syrian citizens suspected of involvement in the murder of former Prime Minister of the Lebanon, Rafiq Hariri, in 2005. However, no additional sanctions are imposed against Syria despite the recent accusations to acquire and re-sell equipment and technologies related to weapons of mass destructions.

The significant violations of human rights and instable internal situation in Myanmar/Burma and Zimbabwe led to the EU sanctions being ones of the broadest restrictions regarding their scope and including prohibition to sell military equipment, freezing of assets belonging to governmental officials and their family members and prohibition to enter the territory of the Union. As the situation in these countries does not seem to improve, sanctions are increasingly enhanced - usually the control lists are revised and this job is usually done according to the reports of the EU embassies in these states. 


\subsubsection{EU Arms Embargo Imposed to China}

Embargo on military equipment imposed by the EU to China can be considered as one of the eldest sanctions, which were adopted at the EU summit in Madrid just after the brutal repressions of Chinese military against a peaceful demonstration on the Tiananmen Square in 1989. This prohibitions still survives nowadays but it is criticized more frequently and even bypassed by some EU member states due to its uncertainty.

In 1989 the Community did not have a common sanctions policy nor did the Common Foreign and Security Policy of the European Union exist ${ }^{26}$. A political obligation not to sell military equipment to China was set out in the political Madrid Declaration. This short document does not contain any scope of arms embargo nor did the EU have a common list of military equipment, which is the current reference point upon imposing arms embargoes nor there existed any mechanism on how to implement these sanctions and verify them (e.g. as of 1999 the EU member states have to submit annual reports on arms sales).

In a later stage, the EU arms embargoes imposed to third countries and regarded as measures of the Common Foreign and Security Policy were better defined in details laying down concrete objects of restrictions, validity periods and procedures of their revision. This inaccurate situation about arms embargo on China caused a situation when some states circumvented it and sold different military equipment to $\mathrm{China}^{27}$; there was also a clear disagreement among the EU member states whether the embargo covers any type of military equipment or only, for instance, the so-called "lethal" one ${ }^{28}$. During the recent years, these considerations became more mainstream having watched the rising Chinese economy military reforms being carried out, especially rearming the Chinese (People's Liberation) Army. Significant amounts of military equipment were sold by other Western states as Israel, the USA and Canada and this fact evoke a sound anxiety of China's neighbours.

Last decade noticing a rapid growth of the Chinese economy and an appearance of certain freedoms, the revocation of arms embargo became a topic again. It was considered as a signal bearing a positive assessment of improving situation in the country and encouraging further reforms especially in the area of human rights. These circumstances allowed the issue of revocation of arms embargo on China to become one of the EU foreign policy's instruments giving a chance, as it was comprehended, for the EU to have an effective tool to push and encourage China to change its policy. This idea is set out in the

\footnotetext{
${ }^{26}$ Common Foreign and Security Policy, as a second pillar of the EU, appeared only in the Maastricht Treaty in 1992 when the European Community became European Union.

${ }^{27}$ According to the estimation of Stockholm International Peace Research Institute (SIPRI), China's most significant arms import was carried out from the Russian Federation, France, Israel and the United Kingdom. According to Wezeman S.T., Bromley M., Wezeman P.D., International Arms Transfers, Sipri Yearbook 2009, http://www.sipri.org/yearbook/2009/07, 15122009.

${ }^{28}$ The term "lethal" is sometimes reworded as "dead weapons". It encompasses armored vehicles, aircrafts, vessels, cannons.
} 
Council's Conclusions ${ }^{29}$ adopted during the Dutch presidency over the EU (on 16-17 December 2004) containing a political will to lift up the arms embargo. Member states predicated on the assumption that trade amounts with China were not to grow after the revocation of embargo neither in qualitative nor in quantitative way.

This European position under formation invoked an extensive criticism for the US side and the countries situated close to China, Japan, South Korea and Australia. They asked to pay attention to the possibilities of regional tensions if China possessing new technologies, and if this would start any action against Taiwan. The EU promised its allies not to hurry in actions and carry out a thorough investigation of the regional situation, as well as one to adopt a new biding legislation within the Community on strengthening the control of arms exports.

One of them was a common position, which had to replace the only politically binding ES Code of Conduct on Arms Trade. Another project was the adoption of post-embargo measures ${ }^{30}$ setting out a three-year stricter control for countries after the revocation of embargo upon them. Due to the lack of consensus within the EU, the aforementioned common position was adopted only in December 2008, moreover, the document providing with post-embargo measures were eventually forgotten, however, some EU states unofficially used it in cases of intended arms export because of its logical pre-emptive measures.

It is however interesting that the adoption of this common position in 2008 was not based on a will to lift up arms embargo against China but absolutely different circumstances - after 2004, when the idea of revocation of arms embargo to China was spread out, the EU member states became one of the most active countries supporting the project of an Arms Trade Treaty ${ }^{31}$ to be a control instrument for global trade in military equipment. In discussions the EU cannot simply surrender the critics that, on one hand, it supports stricter arms control and disarmament but, on the other hand, it is not able to reach a consensus within itself on the rules suggested to others. The issues of lifting up arms embargo towards China is halted for some years and is raised only at the meetings with representatives for China's neighbours.

This example on EU's attempts to manipulate the issue of sanctions towards China can clearly demonstrate the EU's will to use an instrument of sanctions in order to achieve its political ends (the Madrid Declaration itself

\footnotetext{
${ }^{29}$ Council Conclusions adopted on 16-17 December 2004 is available on the EU Council website http:// www.consilium.europa.eu/ueDocs/cms Data/docs/pressData/en/ec/83201.pdf, 15122009.

${ }^{30}$ It is the so-called "Tool-box" setting out such measures as regular exchange of information about the country when the sanctions towards it were lifted up, detailed examination of licenses to export military equipment.

${ }^{31}$ Arms Trade Treaty is a still an idea to adopt an international treaty binding all parties and setting out minimal standard for arms sales: for example, not to sell them to countries where human rights are violated or under military conflicts. More about EU activities in this area at http://www.consilium.europa.eu/showPage.aspx?id=1484\&lang=en\#exp7, 15122009.
} 
has defined the purely political nature of this issue). Nevertheless, the EU lacks the political will to finish with this question and reach some concrete results for the time being - firstly, there is no consensus among the member states, secondly, still a severe reaction from the partners exist. The EU linked this issue with the adoption of certain documents which seemed to be more useful for other purposes than elevating China's question or just facilitating everyday activities of national institutions of the member states, so they were naturally used. One more important factor was an entirely technical comprehension that existing ES instruments are sufficient in order to limit export of arms and technologies to China but on the other hand it enable them to circumvent the embargo and sell desired equipment to $\mathrm{China}^{32}$. This situation was satisfying countries supporting both options - even bigger states developing trade with China, as well as such states as Scandinavian countries emphasizing the respect for human rights.

\subsection{4. "Anti-sanctions"33}

One of the strangest sanctions imposed by the EU is the prohibition to satisfy certain claims which can be submitted against the EU subjects by Haiti, Iraq, Libya and Serbia due to former restrictions when these countries were under sanctions regimes, i.e. arms embargo imposed by the UN, visa bans applied to their citizens and freezing of assets. If after the sanctions were revoked, there is an obligation in force for the EU member states to retain measures necessary to protect the interests of EU subjects from the claims stemming out from former arrangements and deals the, implementation of which was affected by the UNSC resolutions imposing those sanctions. The sanctions differ in their principle from common sanctions imposed by the UN or EU to the extent that they have no concrete restrictions towards the subjects of third countries but directly protect the interest of EU citizens.

If in the latter case, the EU transposed the obligations of the UN sanctions, the EU sanctions against the USA could be described as absolutely autonomous. The USA is among a small group of states that the legislation of which could have an exterritorial application, i.e. this legislation could cause legal effects in a foreign country. However, this practice can be enforced if the competent authorities of that foreign country accommodate such a piece of legislation having an extraterritorial applicability in their further legislation.

Having this motive in mind, the EU adopted a common position and relevant regulation not recognizing the principle of exterritorial effect included

\footnotetext{
${ }^{32}$ For instance, it is possible to sell hardly defined or ultramodern technologies via third countries bearing in mind that those technologies are not listed in the yearly renewable EU Common Military List..

${ }^{33}$ In legal literature two terms are defined: "countermeasure" and "sanctions". For the first case, the impact of other country is temporary limited, for the second case, "sanctions" are a means of punishment. According to Evans M., ed., International Law, 2nd Edition, Oxford University Press, 2006, p. 524.
} 
in some EU legislation. The EU clearly emphasizes the application of national legislation to other countries constitutes a breach on international law, so it generates an obligation for the EU to protect its citizens and other entities according to its own law. These is a tangible purpose of this prohibition set out as well - the Union endeavours to achieve to the greatest extent possible the objective of free movement of capital between member states and third countries, including the removal of any restrictions on direct investment - including investment in real estate - establishment, the provision of financial services or the admission of securities to capital markets ${ }^{34}$. In addition there is an obligation for the EU subject to inform the Commission in case of such actions of third countries.

The Council regulation ${ }^{35}$ setting out these positive sanctions even contains a list of certain EU legislation having an exterritorial application - i.e. sanctions against Cuba, Iran and Libya all of them imposed in 1996. These sanctions provides with obligations to maintain a global economic embargo and cancel all financial relations with Cuba as it is implemented in the USA, in case of Iran and Libya - to waive considerable investments to oil industries of these countries. The regulation also demonstrates possible damage for EU interests, namely, legal proceedings in the USA, forfeiture, fines, and imprisonment in cases of violation.

Apparently such EU "anti-sanctions" expose two-fold purposes of the $\mathrm{EU}$ - to protect the interests of its citizens and other entities and implement the international sanction imposed only by international organizations but no restrictions of separate states. In most of the EU member states a similar principal is under respect - the sanctions imposed by third countries are not biding and can only be regarded as for recommendation. For the conclusion, one must remember that in Lithuania there are only rules for implementation of international sanctions adopted (according to the aforementioned Law on the Implementation of Economic and Other International Sanctions of 2004) but there no provisions for cases of unilateral sanctions imposed by other countries or on the impositions of purely national ones.

\subsubsection{EU Sanctions against Its Internal Subjects}

After the terrorist attacks on 11 September 2001 in the USA, new action has been taken in order to halt the activities of terrorist groups and curb the provision of assistance to them. On 28 September 2001 the UNSC adopted resolution 1373 (2001) aiming the prohibition of terrorism financing. Even though the funds belonging to Osama bin Laden and his allies were frozen afterwards, the common lists of sanctioned terrorists were substantially enhanced.

\footnotetext{
${ }^{34}$ Council Regulation (EC) No 2271/96 of 22 November 1996 protecting against the effects of the extraterritorial application of legislation adopted by a third country, and actions based thereon or resulting therefrom.

${ }^{35}$ Ibidem.
} 
In this context the EU Council adopted Common Position 2001/931/ CFSP of 27 December 2001 on the application of specific measures to combat terrorism. It provides with a list including not only persons and entities linked to Osama bin Laden or other so-called "traditional" terrorist organizations, for instance, related to Hizballah or Hamas networks, but also organizations and individuals active within the EU and having its citizenship. The most of them are Basques of the ETA organization, among others the Irish Republic Army, Ulster Defence Association and the similar could be found as well ${ }^{36}$. It means that the EU has adopted financial sanctions directed to its own citizens and such restrictions form their nature could not be considered as international. Otherwise, the activities of these entities, despite their local scope, do not differ from practice of international terrorist organizations.

It is worth noting that the abovementioned common position defines which actions could be treated as terrorist ones; however, the EU member states are entitled to finally define the concept of "terrorist act" according to their national law and to the definition of "an offence" therein ${ }^{37}$. It clearly shows that the sole and internationally accepted definition of "terrorism" does not exist.

Upon adoption of financial sanctions against its own citizen, the EU Council could only adopt a common position but no regulation - it means that the political will to restrict the entities in question was conveyed but the EU member states had an obligation to pass national legislation implementing sanctions with concrete measures.

The examples provided demonstrate that the EU adopts sanctions complementing the ones adopted by the UNSC, as well as it imposes unilateral restrictions to third countries, defends its citizens from the sanctions having exterritorial application and even restrains some rights of its citizens - i.e. the EU actively uses international sanctions as an instrument in international politics. The procedures of imposition and application of sanctions are sufficiently explicated, moreover, every member states having an obligation to put into practice the legislation adopted by the Council and Commission shall also set up concrete measures in order to implement international sanctions on national level. Nevertheless, plenty of questions remain on how this instrument of impacting third countries can be effective more than that of a political will or political manifestation. One could ask if the policy of sanctioned countries becomes different after the imposition of sanctions - the last chapter of the article goes on that.

\footnotetext{
${ }^{36}$ Some terrorist organizations have very funny names, for instance, Cooperativa Artigiana Fuoco ed AffiniOccasionalmente Spettacolare (Eng. Artisans' Cooperative Fire and Similar-Occasionally Spectacular). ${ }^{37}$ Point 3 of Article 1 of Council Common Position 2001/931/CFSP of 27 December 2001 on the application of specific measures to combat terrorism.
} 


\section{Other Measures Equating Sanctions}

When writing on arms embargo it is necessary to mention an export control system of military equipment and dual-use goods and technologies effectively operating in every EU member state. In order to export such goods to another state, especially in cases where such states are not EU member states, an export license is to be acquired. The same procedures are applied for cases of brokering, transit and trans-shipment ${ }^{38}$.

Export control of military equipment comes under the framework of the Common Foreign and Security Policy and the principles of control are defined in Council Common Position 2008/944/CFSP of 8 December 2008 defining common rules governing the control of exports of military technology and equipment. This common position has eventually implemented the EU Code of Conduct on Arms Export adopted by the Council in 1998 which was in force until the adoption of the common position. The common position is regarded as a legally binding document setting out eight criteria regarding that which the EU member states decide upon the granting of export licenses for military equipment, mechanism of exchange of information among the states and transparency related measures. The control of dual-use goods, on the other, comes under competence of the Union and is defined in Council Regulation No (EC) Nr. 428/2009 of 5 May 2009 setting up a Community regime for the control of exports, transfer, brokering and transit of dual-use items.

According to these documents, the control lists of military equipment and dual-use goods subject to be licensed by the competent state authorities were approved. Licenses are granted if the importing countries are in line with the abovementioned eight criteria ${ }^{39}$, including, inter alia, the respect for human rights, absence of internal and regional conflicts, fight against terrorism and economic capacity to buy military equipment. The EU member states are also entitled to license the export of goods that are included to the control lists ${ }^{40}$ but could be used for the development of weapons of mass destruction or shipped to sensitive countries.

In reality these requirements often mean that a relative arms embargo could be imposed on certain countries which do not fall under international sanctions. Despite the fact that every case of export is assessed separately on

\footnotetext{
${ }^{38}$ Brokering denotes an activity when sold goods physically do not enter the country where a person organizing such a transaction resides. Transit denotes an activity when goods are carried though the territory of a country and the carrier is neither consignor nor consignee. Trans-shipment denotes an activity when goods during transiting a country are loaded of one means of transport into another one.

${ }^{39}$ Eight criteria: 1) absence of international sanctions against the state, 2) respect for human rights, 3) absence of armed conflicts within the country, 4) regional stability, 5) the countries does not put a risk on national security of allies of exporting country, 6) fight against terrorism, 7) commitments not to re-export the equipment, 8) economic capacity to acquire military equipment.

${ }^{40}$ The so-called "catch-all" procedure set out in Article 4 of Council Regulation No (EC) Nr. 428/2009 of 5 May 2009 setting up a Community regime for the control of exports, transfer, brokering and transit of dual-use items.
} 
national level, the EU member states frequently regard their common policy and do not sell arms if, for instance, human rights are violated in a certain country. It is untrue that if there are no official sanctions imposed to a country arms export could be freely conducted (ref. Table 2 Denied Licenses by the EU Member States to Third Countries in 2007 and 2008).

In conclusion, it is obvious that the EU countries actively pursue this instrument in the context of high level political background as an incapability to reach a decision, for instance, in UN Security Council where the positions of such countries as Russia and China often are different for the positions of the Western states. Exports control is also effective in coercing the countries to change their actual policy, e.g. it is a consensus decision not to sell guns to African countries due to unsatisfying situation of human rights.

In these cases it is important to reach a harmonious decision among the EU member states and it gave reason for their representatives to gather themselves on a regular basis to the meeting of the EU Council Working Party on Conventional Arms Exports (COARM) and to change information on sensitive countries and make decision on the harmonization of national export control systems. In comparison to other countries, the EU has one of the highest export control standards and they allow the EU to possess additional measures to implements its foreign policy beside international sanctions.

\section{The Question of Efficiency of International Sanctions}

The imposition of international sanctions is not a spontaneous objective of an international organization - the sanctions are targeted to change internal or foreign policy of the countries or other subjects in question. Frequently attention is given to the analysis of the process of adopting international sanctions but a more important question remains on their efficiency and the level of it.

To assess an impact of sanctions is a hard task; moreover, the assessment should be different according to object subject to sanctions as sanctions can limit the needs of the elite in power in order to restrain them from the resources or put restriction on the whole society to augment dissatisfaction against the government. Often both cases are to be combined but refraining to wrong unrelated persons and limit basic needs for living.

One of the methods to evaluate the efficiency of sanctions is to look at the fact regarding how many or what sanctions have been lately lifted up. They could partially demonstrate their impact of targeted subjects that caused their needlessness as an instrument for foreign policy. One could assess the duration of their application as well as it gives information on the expediency of sanctions.

Currently the EU applies sanctions to 20 countries excluding persons prosecuted for terrorism and war crimes in former Yugoslavia. A part of these 
sanctions has been imposed more that 10 years ago, for instance, against Sierra Leone and China (even 20 years ago). As of 2006 sanctions were imposed, revised in cases of already being in force or reinforced for the most of the sanctioned countries including Myanmar/Burma, Democratic Republic of the Congo, Republic of Cōte d'Ivoire, Iran, North Korea and Zimbabwe. The list of individuals related to terrorist organizations swells as well - from 2002 to the end of 2009 this list was amended for 118 times.

Unfortunately, there are only several states the sanctions to which were lately repealed or softened: arms embargo and other economic sanctions were lifted up for Angola, Haiti, Libya, Rwanda and states from former Yugoslavia; political (movement) sanctions were temporary suspended for Belarusian officials and repealed for Uzbekistan. There is also some negligible alleviation to sanctioned countries in Africa, Afghanistan and Iraq where the UN or EU missions are deployed and relevant national security forces being rebuilt. It naturally diminishes the scope of sanction applied. It is likely that the last persons indicated by International Criminal Tribunal for the former Yugoslavia would be arrested.

These statistics demonstrate a trend of imposing new sanctions, leaving aside the European will to use them as an instrument for foreign policy. It suggests that sanctions are not ever so effective and giving desired objectives at once. Moreover, they cannot be considered as a primary reaction of the EU to policies of a certain state as well but, for instance, a measure supplementing military missions. That is why in many cases sanctions can be defined only as a minimal reaction of international community directed to unacceptable behaviour of certain countries but not concrete measures to coerce them.

The scope of further enhancement of sanctions and their limits could be apprehended through the case of Iran subject to the EU sanction as of 2007. Despite the fact that the EU member states were expressing certain vigilance when assessing export opportunities towards Iran and had in mind the US restrictions already in force, the official sanctions were imposed only when Iran did not obey the requirements to halt the development of nuclear and missile programs. The embargo encompassed restrictions on trade in arms and dual-use goods, the assets of certain companies and persons were frozen and visa ban was imposed upon them. On a later stage, the EU broadened the UN sanctions in imposing new additions to almost every area of restrictions - it allows us to emphasize that at the moment the sanctions against Iran are the most extensive EU sanctions ever (certainly, they cannot be compared to the entire blockade of Cuba implemented by the USA) $)^{41}$.

Despite these European measures, the policy of Iran does not change ${ }^{42}$. The society suffers (for instance, there is a lack of new technologies and aircrafts get old) but the government do not give up on further plans to develop nuclear program not accessible for international community to monitor it. This

\footnotetext{
${ }^{41}$ In Iranian case, the sanctions against it come even closer to an entire trade embargo describe in theory about international sanctions. Other states portrayed in this article are only subject to partly trade restrictions, for instance, arms embargo. The differences between the entire and partly embargos are laid down in Aust, A., Handbook of International Law, Cambridge University Press, 2005, p. 218.

${ }^{42}$ In December 2009 Iran declined the proposal made by the USA, Russia, France and the International Atomic Energy Agency (IAEA) to continue the enrichment of uranium in Russia and France, so ensuring the right of Iran to pursue a peaceful use of nuclear technologies and uranium afterwards would be appropriate for medical use.
} 
situation keeps on evident doubts for the efficiency of international sanctions and the status is getting even worse as the EU with its allies do not know how to enhance these sanctions as all traditional measures are already used. A strict European foreign policy did not give good results and did not work as leverage in order to attract the Iranian government into negotiations.

Another example of inefficiency of sanctions as an official instrument of international politics arises from the policy of the EU member states in reacting to the Russian military action in Georgia in August 2008. The EU member states, some of which were accused of supplying Georgia with arms and which denied it later on, immediately suspended such exports as it was required in accordance to the criteria of the EU Code of Conduct on Arms Trade (later changed to EU Council Common Position 2008/944/CFSP) when assessing export of military equipment. There was no official arms embargo imposed towards Georgia but the EU member states followed a common policy. It means that there are different measures to limit arms sales and other than legally set out and binding sanctions, as well as this instrument is much time-consuming for its adoption, so not that flexible.

On the other hand, almost nobody spoke on possibilities to impose arms embargo on Russia because it is a senseless thing. Russia is a country being able to produce itself enough of military equipment and much more for the export. Moreover, it is an influential country as well and imposition of arms embargo does not pay off politically (the level of Russian armament does not rely on imports too). The EU is not in a position to repeat the Chinese case with an undefined arms embargo which interrupts ever closer cooperation between the EU and China. Consequently, the EU reacting to the Russian-Georgian conflict can easier and swifter limit the smaller side, i.e. Georgia.

The efficiency of sanction could be also analyzed taking into account the country, the sanctions to which are already repealed - to Angola, Haiti, Libya, Rwanda, Belarus, Uzbekistan and states of former Yugoslavia. They can be distinguished either by their economic underdevelopment or strategic position, the latter being quickly comprehended by their governments. To impose sanctions against relatively poverty-stricken Angola, Haiti and Rwanda and by such means seek to influence their governments is not complicated. Some other actions are required in case of significantly wealthy and larger Iran having internal resources for survival. For this reason the efficiency of sanctions depends on the capabilities of a country to withstand them and it suggests that the instrument of sanctions is not universal.

The group of countries as Belarus, Uzbekistan and, for instance, Bosnia and Herzegovina understand the use of resuming relation with other states especially the neighbouring ones. Closer economic ties and growing economics with well-developed European countries of richer neighbours are a sufficient stimulus to reject their former policy and earn additional and tangible benefit of it. This process could be evaluated twofold: the change in state's policy could be impacted of its lucrative calculation, as well as the subject which has imposed sanctions could choose not to use restrictions but rather to offer a reward. 
Thus, international sanctions might not be the only possible explanation why the policy of sanctioned country has changed.

This idea could also refer to selfish striving of international organization or states being able to impose sanctions to make use of resources owned by a sanctioned country. Libya known as rich in oil and China entitled as a country of tremendous trade opportunities could well be examples. The interests of some states to seize possibilities and seek for economic benefit in many cases compete with principles of expanding the area of democracy and encouraging the respect for human rights. On principle such situation rather weakens the efficiency of international sanctions and the will to use them. This issue might be very salient for the European Union upon imposition of autonomous sanctions - that means that third countries in the absence of universally binding UNSC sanctions could profit by this situation. Moreover, in such a case the EU creates unfavourable conditions for its own citizens and it could be one of even stronger reasons why the governments search for other ways to eventually impose for themselves less "harmful" sanctions formally applied to other countries. The Chinese case of ambiguous arms embargo is good to promote this version.

In conclusion, one could estimate that there are significant difficulties using the instrument of sanctions to seek considerable political objectives in international politics and EU activities. This is the reason why sanctions remain as a signal firstly when the situation in country is negatively evaluated. They are also an indication for the internal and external audience of the EU that the $\mathrm{EU}$ is reacting to internal of foreign policies of other states. However, further implementation meets difficulties because of resistance of the states in question against the sanctions in force (it means these sanctions are not well-developed and therefore ineffective) and internal interests of sanctioning subjects. Despite the fact that international sanctions are the most legal instrument of international law in order to change the policy of other state ${ }^{43}$, the still surviving long list of the states sanctioned by the EU demonstrates that sanctions are not a highly effective instrument of foreign policy.

\section{Conclusions}

The EU policy to impose sanctions, which can be treated as certain nonmilitary coercive measures, is one of the instruments of Common Foreign and Security Policy. The EU completely implements the sanctions imposed by the $\mathrm{UN}$ and has imposed a number of additional or autonomous sanctions.

The implementation of the sanctions adopted by the United Nations Security Council is an evident alleviation for the EU member states which have

${ }^{43}$ Simmons B. A., Steinberg R. H., eds., International Law and International Relations, Cambridge University Press, 2006, p. 335. 
not to pass additional national legislation in this area. Unilateral (autonomous) sanctions are also among the instruments of the Common Foreign and Security Policy which can be used in order to impact foreign policy of certain states. They usually enhance the UN sanctions as a consensus within the Union is naturally more feasible than in the Security Council or the entire UN uniting a number of countries.

There is a conclusion that the EU often uses international sanctions as an instrument of its foreign policy. It demonstrates the will to actively act on the international arena and the appropriate comprehension of the instrument itself as well. At this moment, the EU has imposed sanctions towards 20 states, individuals accused of terrorism and war crimes. The sanctions are followed by the measures of export control of military equipment and dual-use goods, so sanctions could be considered as one of the most institutionalized instruments of EU foreign policy.

Despite its broad application, it is evident that sanctions often meet difficulties in leading to desired political goals - this could be seen in the list of sanctioned states never being shorter. On the other hand, their contents and scope could not match the reality and the principle of expediency is infringed. This reason suggests that sanctions are primarily a political signal to warn a third country that its internal or foreign policy is negatively assessed.

The inefficiency of international sanctions is also caused by the reluctance of international organizations and separate states imposing them to "punish" countries for the breach of principles imbedded in the Charter of the United Nations, for instance, for violation for human rights. This policy inconsistent to unquestioned values is mostly based on economic interests which has a tendency to augment due to globalization, current economic and financial crisis and decline in energy resources.

International sanctions in Lithuania are implemented adopting resolutions of the Government in absence of directly applicable EU regulations - it can be described as a technical job for competent institutions. It is important to emphasize that Lithuania has no legal basis to impose unilateral restrictions that could be considered as sanctions. Lithuania being a member of the United Nations, European Union or OSCE, which are entitled to impose international sanctions will not be able to avoid discussions on the efficiency of these sanctions and a decision whether it is worth to adopt them having in mind economic interests as well. 


\section{Appendixes}

Table 1. International Sanctions Applied Currently

\begin{tabular}{|c|c|c|c|}
\hline Country & $\begin{array}{l}\text { Organization } \\
\text { Imposing } \\
\text { Sanctions }\end{array}$ & Sanctions & Remarks \\
\hline Armenia & $\mathrm{OSCE}^{44}$ & - Arms embargo & $\begin{array}{l}\text { Applied only to } \\
\text { subjects involved } \\
\text { in Nagorno- } \\
\text { Karabakh } \\
\text { conflict }\end{array}$ \\
\hline Azerbaijan & OSCE & - Arms embargo & $\begin{array}{l}\text { Applied only to } \\
\text { subjects involved } \\
\text { in Nagorno- } \\
\text { Karabakh } \\
\text { conflict }\end{array}$ \\
\hline Belarus & EU & $\begin{array}{l}\text { - Political sanctions } \\
\text { - Freezing of funds }\end{array}$ & $\begin{array}{l}\text { Applied } \\
\text { to certain } \\
\text { government } \\
\text { officials, political } \\
\text { sanctions } \\
\text { suspended until } \\
31 \text { October } 2010\end{array}$ \\
\hline $\begin{array}{l}\text { Bosnia and } \\
\text { Herzegovina }\end{array}$ & $\mathrm{UN}$ and EU & - Freezing of funds & $\begin{array}{l}\text { Applied to } \\
\text { individuals } \\
\text { indicated by } \\
\text { International } \\
\text { Criminal } \\
\text { Tribunal for } \\
\text { the former } \\
\text { Yugoslavia }\end{array}$ \\
\hline China & EU & - Arms embargo & $\begin{array}{l}\text { Adopted in } \\
1989 \text { by the } \\
\text { political Madrid } \\
\text { Declaration after } \\
\text { the events on } \\
\text { the Tiananmen } \\
\text { Square }\end{array}$ \\
\hline $\begin{array}{l}\text { Republic of } \\
\text { Cōte d'Ivoire }\end{array}$ & $\mathrm{UN}$ and EU & $\begin{array}{l}\text { - Arms embargo } \\
\text { - Political sanctions } \\
\text { - Freezing of funds } \\
\text { - Prohibition to import } \\
\text { diamond into the EU }\end{array}$ & \\
\hline
\end{tabular}

${ }^{1}$ Statement by Committee of Senior Officials of the Conference on Security and Co-operation in Europe, Annex 2 to Journal of the Eighth Meeting of the Committee, 13 March 1992. 


\begin{tabular}{|c|c|c|c|}
\hline Croatia & UN and EU & $\begin{array}{l}\text { - Freezing of funds } \\
\text { - Visa ban }\end{array}$ & $\begin{array}{l}\text { Applied to } \\
\text { individuals } \\
\text { indicated by } \\
\text { International } \\
\text { Criminal } \\
\text { Tribunal for } \\
\text { the former } \\
\text { Yugoslavia }\end{array}$ \\
\hline $\begin{array}{l}\text { Democratic } \\
\text { People's } \\
\text { Republic of } \\
\text { Korea } \\
\text { (North } \\
\text { Korea) }\end{array}$ & UN and EU & $\begin{array}{l}\text { - Arms embargo } \\
\text { - Embargo on dual-use } \\
\text { goods } \\
\text { - Prohibition to buy } \\
\text { certain technologies } \\
\text { - Political sanctions } \\
\text { - Freezing of funds } \\
\text { - Inspection of cargoes } \\
\text { from North Korea } \\
\text { - Prohibition to sell luxury } \\
\text { goods }\end{array}$ & \\
\hline $\begin{array}{l}\text { Democratic } \\
\text { Republic } \\
\text { of the Congo }\end{array}$ & UN and EU & $\begin{array}{l}\text { - Arms embargo } \\
\text { - Political sanctions } \\
\text { - Freezing of funds }\end{array}$ & \\
\hline Haiti & EU & $\begin{array}{l}\text { Prohibition to satisfy } \\
\text { claims against EU } \\
\text { subjects }\end{array}$ & \\
\hline Iran & UN and EU & $\begin{array}{l}\text { - Arms embargo } \\
\text { - Embargo on dual-use } \\
\text { goods } \\
\text { - Prohibition to buy certain } \\
\text { technologies } \\
\text { - Political sanctions } \\
\text { - Freezing of funds } \\
\text { - Prohibition on certain } \\
\text { investments and financial } \\
\text { relations } \\
\text { - Prohibition to instruct } \\
\text { specialists } \\
\text { - Inspection of cargoes } \\
\text { from Iran }\end{array}$ & \\
\hline
\end{tabular}




\begin{tabular}{|c|c|c|c|}
\hline Iraq & $\mathrm{UN}$ and EU & $\begin{array}{l}\text { - Arms embargo } \\
\text { - Freezing of funds } \\
\text { - Restrictions to trade in } \\
\text { cultural goods } \\
\text { - Duty to transfer benefits } \\
\text { acquired by selling oil to } \\
\text { Development Fund for } \\
\text { Iraq } \\
\text { - Prohibition to satisfy } \\
\text { claims against EU } \\
\text { subjects }\end{array}$ & \\
\hline Lebanon & $\mathrm{UN}$ and EU & $\begin{array}{l}\text { - Arms embargo } \\
\text { - Political sanctions } \\
\text { - Freezing of funds }\end{array}$ & $\begin{array}{l}\text { Applied to } \\
\text { individuals } \\
\text { suspected of } \\
\text { involvement in } \\
\text { the murder of } \\
\text { former Prime } \\
\text { Minister of the } \\
\text { Lebanon, Rafiq } \\
\text { Hariri }\end{array}$ \\
\hline Liberia & UN and EU & $\begin{array}{l}\text { - Arms embargo } \\
\text { - Political sanctions } \\
\text { - Freezing of funds }\end{array}$ & $\begin{array}{l}\text { The prohibition } \\
\text { to import timber } \\
\text { and diamonds } \\
\text { was in force until } \\
2007\end{array}$ \\
\hline Libya & EU & $\begin{array}{l}\text { - Prohibition to satisfy } \\
\text { claims against EU } \\
\text { subjects }\end{array}$ & \\
\hline $\begin{array}{l}\text { Macedonia } \\
\text { (Former } \\
\text { Yugoslav } \\
\text { Republic) }\end{array}$ & EU & - Political sanctions & $\begin{array}{l}\text { Applied } \\
\text { to persons } \\
\text { challenging } \\
\text { the Ohrid } \\
\text { Framework } \\
\text { Agreement }\end{array}$ \\
\hline
\end{tabular}




\begin{tabular}{|c|c|c|c|}
\hline Moldova & EU & - Political sanctions & $\begin{array}{l}\text { Applied to } \\
\text { individuals } \\
\text { responsible } \\
\text { for the broad } \\
\text { intimidation } \\
\text { and closure } \\
\text { campaign } \\
\text { against teachers, } \\
\text { parents and } \\
\text { students of } \\
\text { Latin-script } \\
\text { Moldovan } \\
\text { schools in the } \\
\text { Transnistrian } \\
\text { region }\end{array}$ \\
\hline $\begin{array}{l}\text { Myanmar } \\
\text { (Burma) }\end{array}$ & UN and EU & $\begin{array}{l}\text { - Arms embargo } \\
\text { - Prohibition to buy certain } \\
\text { - Political sanctions } \\
\text { - Freezing of funds } \\
\text { - Suspension of aid } \\
\text { and development } \\
\text { programmes } \\
\text { - Suspension of high level } \\
\text { bilateral governmental } \\
\text { visits } \\
\text { - Reduction of diplomatic } \\
\text { relations }\end{array}$ & \\
\hline Serbia & UN and EU & $\begin{array}{l}\text { - Political sanctions } \\
\text { - Freezing of funds } \\
\text { - Prohibition to satisfy } \\
\text { claims against EU } \\
\text { subjects }\end{array}$ & $\begin{array}{l}\text { Applied to } \\
\text { individuals } \\
\text { indicated by } \\
\text { International } \\
\text { Criminal } \\
\text { Tribunal for } \\
\text { the former } \\
\text { Yugoslavia }\end{array}$ \\
\hline Sierra Leone & UN and EU & $\begin{array}{l}\text { - Arms embargo } \\
\text { - Political sanctions }\end{array}$ & \\
\hline Somalia & UN and EU & $\begin{array}{l}\text { - Arms embargo } \\
\text { - Political sanctions } \\
\text { - Freezing of funds }\end{array}$ & \\
\hline Sudan & UN and EU & $\begin{array}{l}\text { - Arms embargo } \\
\text { - Political sanctions } \\
\text { - Freezing of funds }\end{array}$ & \\
\hline
\end{tabular}




\begin{tabular}{|c|c|c|c|}
\hline Syria & $\mathrm{UN}$ and $\mathrm{EU}$ & $\begin{array}{l}\text { - Political sanctions } \\
\text { - Freezing of funds }\end{array}$ & $\begin{array}{l}\text { Applied to } \\
\text { individuals } \\
\text { suspected of } \\
\text { involvement in } \\
\text { the murder of } \\
\text { former Prime } \\
\text { Minister of the } \\
\text { Lebanon, Rafiq } \\
\text { Hariri }\end{array}$ \\
\hline $\begin{array}{l}\text { United States } \\
\text { of America }\end{array}$ & EU & $\begin{array}{l}\text { - Prohibition to satisfy } \\
\text { claims against EU } \\
\text { subjects }\end{array}$ & \\
\hline Uzbekistan & EU & $\begin{array}{l}\text { - Political sanctions } \\
\text { - Arms embargo }\end{array}$ & $\begin{array}{l}\text { Repealed } \\
\text { respectively in } \\
2008 \text { and } 2009 \\
\end{array}$ \\
\hline Zimbabwe & $\mathrm{EU}$ & $\begin{array}{l}\text { - Arms embargo } \\
\text { - Political sanctions } \\
\text { - Freezing of funds }\end{array}$ & \\
\hline $\begin{array}{l}\text { Members } \\
\text { of Al } \\
\text { Qaeda and } \\
\text { Taliban and } \\
\text { individuals } \\
\text { relating to } \\
\text { Usama bin } \\
\text { Laden, other } \\
\text { terrorist } \\
\text { organi- } \\
\text { zations }\end{array}$ & $\mathrm{UN}$ and EU & $\begin{array}{l}\text { - Arms embargo } \\
\text { - Political sanctions } \\
\text { - Freezing of funds }\end{array}$ & $\begin{array}{l}\text { Sometimes it is } \\
\text { indicated that, } \\
\text { for instance, } \\
\text { arms embargo } \\
\text { is applied to } \\
\text { Afghanistan } \\
\text { The so-called } \\
\text { EU "internal } \\
\text { terrorists", i.e. } \\
\text { citizens of the } \\
\text { EU, are included } \\
\text { under the } \\
\text { other terrorist } \\
\text { organizations. }\end{array}$ \\
\hline
\end{tabular}

${ }^{45}$ Resolution of the Government of 1 March 2005 No 237 "On the Approval of the List of the States to Which the Export or Transit of the Goods Listed in the Common Military List is Prohibited and for which Brokering in Negotiations and Transactions in the Goods Listed in the Common Military List is Prohibited". 
Table 2. Denied Licenses by the EU Member States to Third Countries in 2007 and $2008^{46}$

\begin{tabular}{|c|c|c|}
\hline & \multicolumn{2}{|c|}{ Denied Licences } \\
\hline Country & 2007 & 2008 \\
\hline Afghanistan & 2 & 0 \\
\hline Albania & 0 & 1 \\
\hline Algeria & 8 & 2 \\
\hline Andorra & 4 & 2 \\
\hline Angola & 3 & 1 \\
\hline Argentina & 0 & 2 \\
\hline Armenia & 3 & 6 \\
\hline Azerbaijan & 10 & 4 \\
\hline Bangladesh & 14 & 8 \\
\hline Belarus & 3 & 2 \\
\hline Belize & 1 & 0 \\
\hline Bosnia and Herzegovina & 1 & 4 \\
\hline Botswana & 1 & 1 \\
\hline Brazil & 2 & 1 \\
\hline Bulgaria & 0 & 1 \\
\hline Burkina Faso & 0 & 1 \\
\hline Cambodia & 0 & 1 \\
\hline Cameroon & 0 & 1 \\
\hline Canada & 1 & 0 \\
\hline Central African Republic & 11 & 1 \\
\hline Chad & 7 & 4 \\
\hline Chile & 1 & 0 \\
\hline China & 47 & 30 \\
\hline Columbia & 2 & 0 \\
\hline Croatia & 1 & 0 \\
\hline Cuba & 1 & 0 \\
\hline Cyprus (Northern) & 0 & 2 \\
\hline Czech Republic & 1 & 0 \\
\hline $\begin{array}{l}\text { Democratic Republic } \\
\text { of the Congo }\end{array}$ & 0 & 2 \\
\hline Ecuador & 1 & 2 \\
\hline Egypt & 10 & 13 \\
\hline Ethiopia & 4 & 0 \\
\hline Georgia & 16 & 11 \\
\hline Ghana & 0 & 1 \\
\hline Guatemala & 3 & 0 \\
\hline
\end{tabular}

${ }^{46}$ Compiled according to the Tenth and Eleventh EU Reports on exports of military equipement: http://eur-lex.europa.eu/LexUriServ/LexUriServ.do?uri=OJ:C:2008:300:0001:0374:EN:PDF and http://eur-lex.europa.eu/LexUriServ/LexUriServ.do?uri=OJ:C:2009:265:FULL:EN:PDF 


\begin{tabular}{|c|c|c|}
\hline Guinea & 0 & 3 \\
\hline Hong Kong ${ }^{47}$ & 2 & 0 \\
\hline India & 11 & 10 \\
\hline Indonesia & 6 & 1 \\
\hline Iran & 23 & 3 \\
\hline Iraq & 0 & 6 \\
\hline Israel & 28 & 22 \\
\hline Jamaica & 3 & 0 \\
\hline Jordan & 7 & 1 \\
\hline Kazakhstan & 1 & 3 \\
\hline Kenya & 1 & 1 \\
\hline Lebanon & 5 & 3 \\
\hline Liberia & 1 & 1 \\
\hline Libya & 6 & 7 \\
\hline Macao $^{48}$ & 1 & 3 \\
\hline Macedonia (F.Y.R.) & 5 & 1 \\
\hline Malaysia & 1 & 1 \\
\hline Maldives & 1 & 0 \\
\hline Mauritius & 0 & 1 \\
\hline Moldova & 1 & 1 \\
\hline Myanmar (Burma) & 0 & 1 \\
\hline Namibia & 1 & 2 \\
\hline Nepal & 4 & 2 \\
\hline New Zealand & 1 & 0 \\
\hline Nicaragua & 1 & 1 \\
\hline Nigeria & 3 & 4 \\
\hline North Korea & 0 & 1 \\
\hline Oman & 1 & 0 \\
\hline Pakistan & 19 & 23 \\
\hline Panama & 2 & 0 \\
\hline Paraguay & 2 & 1 \\
\hline Peru & 1 & 0 \\
\hline Philippines & 6 & 2 \\
\hline Republic of Côte d'Ivoire & 1 & 3 \\
\hline Republic of the Congo & 1 & 0 \\
\hline Russian Federation & 7 & 8 \\
\hline Rwanda & 1 & 1 \\
\hline Senegal & 0 & 1 \\
\hline Serbia & 1 & 5 \\
\hline Sierra Leone & 0 & 4 \\
\hline Singapore & 0 & 1 \\
\hline South Africa (Republic of ) & 2 & 4 \\
\hline South Korea & 2 & 1 \\
\hline Sri Lanka & 23 & 33 \\
\hline
\end{tabular}

${ }^{47}$ Officially EU regards Hong Kong as a part of China.

${ }^{48}$ Officially EU regards Macao as a part of China. 


\begin{tabular}{|l|c|c|}
\hline Sudan & 3 & 2 \\
\hline Suriname & 5 & 0 \\
\hline Switzerland & 1 & 0 \\
\hline Syria & 5 & 0 \\
\hline Taiwan & & 9 \\
\hline Tanzania & 17 & 0 \\
\hline Thailand & 2 & 2 \\
\hline Timor-Leste & 3 & 4 \\
\hline Trinidad and Tobago & 1 & 2 \\
\hline Tunisia & 0 & 3 \\
\hline Turkey & 3 & 1 \\
\hline Uganda & 0 & 2 \\
\hline Ukraine & 5 & 7 \\
\hline United Arab Emirates & 11 & 0 \\
\hline Uzbekistan & 1 & 1 \\
\hline Venezuela & 2 & 10 \\
\hline Vietnam & 12 & 2 \\
\hline Yemen & 6 & 5 \\
\hline Zambia & 4 & 0 \\
\hline Zimbabwe & 1 & 0 \\
\hline
\end{tabular}

